\& J. Edu. \& Sci., Vol. (24), No. (3) 2011 y

\title{
Detection of Immunoglobulin $G$ and $M$ Antibodies to Helicobacter Pylori in Serum by an Enzyme Immunoassay Method
}

\author{
Pakshan Abdulla Hassan \\ Department of Biology / College of Science \\ University of Salahaddin / Kurdistan Region, Iraq
}

Received

$26 / 04 / 2010$
Accepted

27 / 06 / 2010

\section{الخلاصة}

في هذه الدراسة تم الكثف عن عدوى الملوية البوابية (Helicobacter pylori) باستخدام تقنية الايالايزا (ELISA) لتحديد امكانية استخدام الفحوصات العصلية في تتخيصها ، ولذلك الغرض تم الكثف عن مضادات الملوية البوابية (Anti H.pylori) من نوع IgG و IgM في عينات مصل

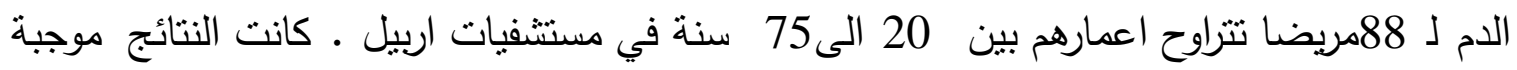

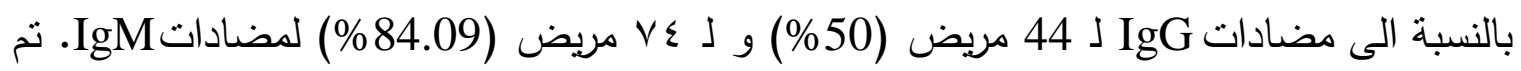

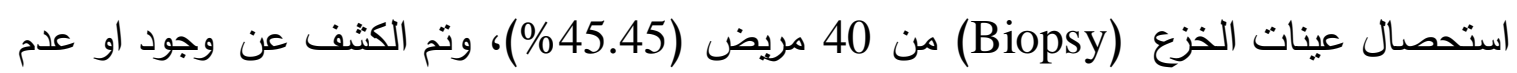

وجود الاصابة ب H.pylori بثلاث طرق: الزرع الجرثومي ، الكثف عن انزيم اليوريس وطريقة

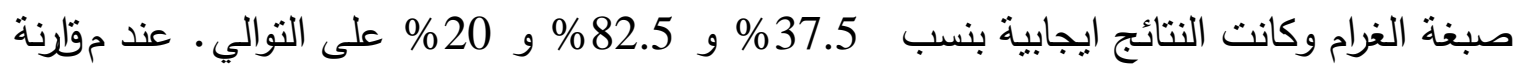

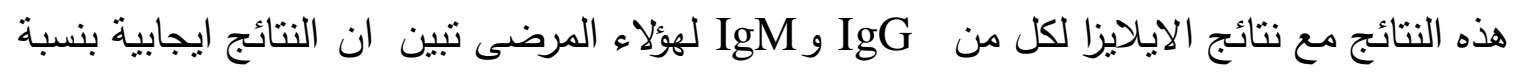

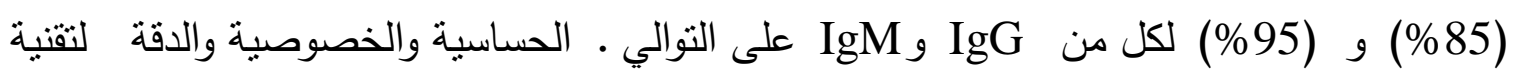

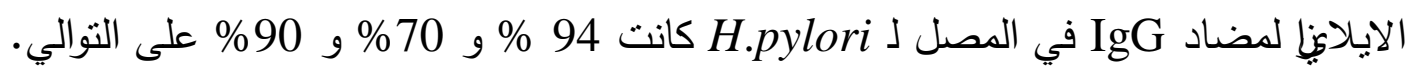

\section{ABSTRACT}

The aim of this study was to detect Helicobacter pylori infection using an enzyme-linked immunosorbent assay (ELISA) to determine whether serological tests can be used for diagnosis. Serum samples were collected from 88 patients (ages ranges between 20 to 75 years) attending for gastrointestinal endoscopy in Erbil hospitals for detection of anti- 
Helicobacter pylori specific IgG and IgM antibodies in these specimens. IgG and IgM were positive in 44(50\%) and 74 (84.09\%), respectively. Biopsy specimens were collected from $40(45.45 \%)$ of these 88 patients. The presence or absence of current $H$. pylori infection was determined by culture, urease and gram stain, that were positive in $37.5 \%, 82.5 \%$ and $20 \%$, respectively which compared with their $\operatorname{IgG}(85 \%)$ and $\operatorname{IgM}(95 \%)$ respectively. The sensitivity, specificity and accuracy of the assay for serum IgG to $H$. pylori were $94 \%, 70 \%$ and $90 \%$ respectively.

Key Words: Helicobacter pylori, Immunoglobulins, ELISA

\section{INTRODUCTION}

Helicobacter pylori is a spiral-shaped microaerophilic gram-negative bacterium that is often observed in the mucous layer that coats the gastric mucosa (1). Helicobacter pylori is a causative agent in chronic gastritis (2), peptic ulcers (3), and gastric cancer (4). The detection of antibodies specific to $H$. pylori in serum is important in the diagnosis of these diseases (5). However, H. pylori infections occur in the gastric mucosa (6) Multiple invasive and noninvasive methods are available for the detection of Helicobacter pylori (7). Invasive methods necessitate endoscopy and require gastric tissue. They include tests for urease activity, histological evaluation, and culture of the bacterium (8-10). Noninvasive techniques to detect bacterial infection include urea breath tests (UBT) and anti-H. pylori antibody detection by serologic methods. Use of noninvasive methods of detecting $H$. pylori is imperative when screening an unselected population. Serologic tests offer high sensitivity and specificity (11-13); furthermore, simultaneous measurement of serum immunoglobulin $\mathrm{G}(\mathrm{IgG}), \mathrm{M}(\operatorname{IgM})$, and $\mathrm{A}(\operatorname{Ig} \mathrm{A})$ antibodies to $H$. pylori can be used to determine the prevalence of both acute and chronic infection $(14,15)$. Serological tests are useful in $H$. pylori infection because virtually all patients colonized with this organism undergo a local antibody response directed against antigens covering the surface and flagella of the organisms; in the majority of cases this antibody response is also detectable in the serum (16-18). Specific immunoglobulin $\mathrm{M}(\mathrm{IgM})$ antibodies can be detected shortly after the infection is acquired, but IgA and IgG titers indicate chronic infection (19). Enzyme -linked immunosorbent assays (ELISA) have become widely used to detect $H$. pylori antibodies in serum (20- 22). Serological tests for $H$. pylori are advocated to replace endoscopy as a primary diagnostic procedure in patients under the age of 45 years $(23,24)$. 
The object of this study was to detect IgG and IgM antibodies in the serum of $H$. pylori patient by EIA method, comparing this with culture, stain and urease detection.

\section{MATERIALS AND METHODS PATIENTS.}

Serum samples were obtained from 88 adults ( 34 females and 54 males, ages 20 to 75 years [mean, 43 years] presenting with upper gastrointestinal symptoms requiring endoscopic evaluation to the Gastroenterology Department at the two General Hospitals in Erbil, (Rizgary and educational hospital). Serum was stored at $-20^{\circ} \mathrm{C}$ until assayed. Antral biopsy specimens were obtained from 40 of these patients.

\section{MICROBIOLOGY:}

Culture: The biopsy specimens for microbiological analysis were collected into tubes containing $0.9 \%$ saline, and there were transferred to the microbiology laboratory and processed within an hour. One piece of the biopsy specimen was cut, homogenized and inoculated on Brucella agar, Brain heart infusion agar and Blood agar, all three media supplemented with $5 \%$ human blood and amphotericin B (2 mg/l), trimethoprim $(10 \mathrm{mg} / \mathrm{l})$ and vancomycin $(10 \mathrm{mg} / \mathrm{ml})$, (all three media from Accumix). Plates were incubated at $37 \mathrm{C}^{0}$ in a micro-aerophilic atmosphere in a humid chamber for a period ranging from 3 to 10 days. Suspicious isolates were identified H.pylori was identified as small translucent colonies, identification of cultures was based on Gram staining, oxidase and catalase activities, and urease positivity.

Modified Gram Staining: One piece of the biopsy specimen was cut and used for staining (In modified gram $0.2 \%$ carbolfuchsin instead of safranin for counter stain (25). Biopsies were crushed between two slides. Slides were fixed and were stained with carbolfuchsin and Gram stain to record morphology and the presence of Helicobacter- like organisms.

Urease test of biopsies: One of the biopsies was inoculated on urea agar (Oxoid urea agar base) slant tube by streaking the surface of the slant and stabbing the butt of the tube all the way to the bottom, immediately were incubated at $37^{\circ} \mathrm{C}$ for $24 \mathrm{~h}$ (the tubes were checked every $30 \mathrm{~min}$ ). Positive reaction was indicated when tube color changed to pink Patients were considered as H.pylori-positive either if H.pylori was cultured from the biopsies or if urease test of biopsies was positive and as H.pylori-negative if both the culture for H.pylori and urease test were negative. 
Serology: Blood (5 to $10 \mathrm{ml}$ ) was taken from the patients The serum was separated and stored at $-20^{\circ} \mathrm{C}$ until the EIAs' were done. For serology studies. Anti- $H$. pylori IgG and IgM antibodies were tested in all samples by an enzyme immunosorbent assay (ELISA) test.

ELISA Test: Helicobacter pylori IgM enzyme immunoassay and Helicobacter pylori IgG enzyme immunoassay test kits (BioCheck, Inc) were performed according to the manufacturer's instructions. Briefly, the serum was diluted 1:40 for both kits (the EIA-G and the EIA-M). The diluted serum samples $(100, \mathrm{ul})$ and four ready-to-use reference serum samples were pipetted into appropriate microtiter wells (the H. pylori IgM or IgG specific antibody, if present, binds to the antigen), and the plates were incubated for $30 \mathrm{~min}$ at room temperature. The microtiter wells were washed 4 times with diluted wash buffer $(1 \mathrm{x})$ and one time with distilled water, 100 $\mu l$ of Enzyme conjugate was added to each well (which binds to the antibody-antigen complex.) and the plates were incubated for $30 \mathrm{~min}$ at room temperature. The microtiter wells were washed 4 times with diluted wash buffer $(1 \times)$ and then one time with distilled water. $100 \mu \mathrm{l}$ of TMB Reagent was added to each well, Incubated at room temperature for 20 minutes. After stopping the enzyme reaction with stopping solution $(100 \mu 1)$ to each well. The results were recorded using a spectrophotometer within 15 minutes with a microtiter plate reader at wave length of $450 \mathrm{~nm}$. The results are read by a microwell reader compared in a parallel manner with calibrator and controls. The calculated ELISA was read as negative if the ELISA value of both $\operatorname{IgG}$ and $\operatorname{IgM}$ is less than 0.90 , positive if 1.00 or greater.

\section{RESULTS AND DISCUSSION}

Since infection by $H$. pylori induces the production of systemic antibodies. Serodiagnostic tests permit the rapid, noninvasive, sensitive, and specific detection of $H$. pylori $(28,29)$. Serological detection of $H$. pylori antibodies by well formulated and standardized tests such as ELISA has the ability to replace endoscopy as the diagnostic procedure of choice (30). ELISA is one of the most extensively employed tests, because it is relatively inexpensive, quick, easy to perform, suitable for screening large populations, and capable of detecting class-specific immunoglobulins $(31,32)$. Additionally, growth of the organisms is difficult, and recent evidence indicates that at best only $71 \%$ of $H$. pylori strains will grow in a specific medium (33). For best results, several selective media with various antibiotic supplements in addition to at least one nonselective medium would be required to provide the highest culture recovery rates. The presence of specific $H$. pylori- 
directed IgG antibodies has shown excellent correlation with the presence of H. pylori enteric infection (34). A total of 88 patient consented to take part in this study (biopsy specimen collected from 40 of them only). These were 54 men and 34 women, with a mean age of 52.5 years (range 20-75); selected characteristics of the 88 patients examined in the present study are listed in Table (1).

Results of the various tests used in the present study for detection of $H$. pylori are presented in Table (2). Seventy four (84.09\%) of the 88 patients

Table (1): Gender, And Age of 88 Samples of Patients That Used In This Study.

\begin{tabular}{|l|l|}
\hline Characteristic & No. (\%) \\
\hline Gender & \\
\hline Male & $54(61.36)$ \\
\hline Female & $34(38.64)$ \\
\hline Total & $88(100)$ \\
\hline Age groups (yr) & \\
\hline $20-30$ & $17(19.32)$ \\
\hline $30-40$ & $24(27.27)$ \\
\hline $40-50$ & $26(29.55)$ \\
\hline $50-60$ & $12(13.63)$ \\
\hline $60-70$ & $6(6.82)$ \\
\hline $70-80$ & $3(3.41)$ \\
\hline Total & $88(100 \%)$ \\
\hline
\end{tabular}

were positive for $\operatorname{IgM},(50 \%)$ of them were with positive $\operatorname{IgG}$ and only ten $(11.36 \%)$ of the 88 samples were negative for both $\operatorname{IgG}$ and $\operatorname{IgM}$ antibodies the pattern of ELISA results were shown in table (3).

Table (2): Pattern of Results for Culture, modified Gram Stain, urease Detection IgG and IgM (40 Selected Patients).

\begin{tabular}{|c|c|c|c|c|c|}
\hline $\begin{array}{c}\text { No. of } \\
\text { specimens }\end{array}$ & $\begin{array}{c}\text { modified } \\
\text { Gram stain }\end{array}$ & Culture & $\begin{array}{c}\text { Urease } \\
\text { Test }\end{array}$ & IgG & IgM \\
\hline 5 & + & + & + & + & + \\
\hline 9 & - & + & + & + & + \\
\hline 3 & + & - & + & + & + \\
\hline 1 & - & + & + & - & + \\
\hline 4 & - & - & - & - & + \\
\hline 2 & - & - & - & + & + \\
\hline 14 & - & - & + & + & + \\
\hline 1 & - & - & + & + & - \\
\hline 1 & - & - & - & - & - \\
\hline
\end{tabular}


Table (3): No. and Percent of Patterns of ELISA Results.

\begin{tabular}{|l|c|c|}
\hline Serum samples & IgG & IgM \\
\hline $40(45.45 \%)$ & + & + \\
\hline $34(38.64 \%)$ & - & + \\
\hline $4(4.54 \%)$ & + & - \\
\hline $10(11.36 \%)$ & - & - \\
\hline
\end{tabular}

The gastric biopsy specimens of 40 dyspeptic patients, $H$. pylori was found by urease detection, culture, gram staining, $\operatorname{IgG}$, and $\mathrm{IgM}$ in $33(82.5 \%)$, $15(37.5 \%), 8(20 \%),(85 \%)$, and $(95 \%)$, respectively table (4). thirty three $(85 \%)$ of the 40 patients were positive $H$. pylori by one or more of the 'gold standard' tests (culture, gram stain and urease detection). The remaining 7 patients were negative for $H$. pylori by all three tests. only five of the 40 patient were positive for all obtained tests. Compared with bioptic methods (culture, staining, or urease testing), the serum ELISA was $94 \%$ sensitive, $70 \%$ specific and $90.25 \%$ accuracy for the detection of $H$. pylori infection. In comparison between male and female, the infection rate in males was higher than in females, $H$. pylori positivity were $29(65.90 \%)$, and $47(63.51 \%)$ in male and $15(34.09 \%)$ and $27(36.49 \%)$ in female for both IgG and $\mathrm{IgM}$ respectively as in table (5). Table (6) represent the relation between age and ELISA positivity, IgG antibodies were more detected in age (30-40) years old, $31.81 \%$, where IgM decreased with age increasing.

Table (4): Percent pattern of Results for Culture, Modified Gram Stain, Urease Detection IgG and IgM (40 Selected Patients).

\begin{tabular}{|c|c|c|c|c|}
\hline $\begin{array}{c}\text { modified } \\
\text { Gram stain }\end{array}$ & Culture & $\begin{array}{c}\text { Urease } \\
\text { Test }\end{array}$ & IgG & IgM \\
\hline $20 \%$ & $37.5 \%$ & $82.5 \%$ & $85 \%$ & $95 \%$ \\
\hline
\end{tabular}

A wide range of sensitivities and specificities has been reported for detection of $H$. pylori by ELISA (35-37). We determined the presence of anti- $H$. pylori IgG antibodies in the serum of 88 patients using a qualitative ELISA when

Table (5): Comparison Between Gender and ELISA Positivity

\begin{tabular}{|l|l|l|}
\hline Gender & Positive IgG & Positive IgM \\
\hline Female & $15(34.09 \%)$ & $27(36.49 \%)$ \\
\hline Male & $29(65.90 \%)$ & $47(63.51 \%)$ \\
\hline
\end{tabular}


Table (6): Relation Between Age And ELISA Positivity

\begin{tabular}{|l|l|l|}
\hline Age range(year) & \multicolumn{2}{|l|}{ Percent of ELISA positive } \\
\hline & IgG & IgM \\
\hline $20-30$ & $22.73 \%$ & $24.32 \%$ \\
\hline $30-40$ & $31.81 \%$ & $29.73 \%$ \\
\hline $40-50$ & $22.73 \%$ & $27.03 \%$ \\
\hline$>50$ & $22.73 \%$ & $18.92 \%$ \\
\hline
\end{tabular}

compared (only 40 of them) with bioptic methods (culture, staining, or urease testing), and found this to be had a high sensitivity (94\%), and accuracy of $(90.25 \%)$, but low specificity $(70 \%)$ these results in agreement with that found by Perez-Perez et al, 1990 (35); Lin et al, 1996 (36) and Hanvivatvong et al, 2002(37), they reported that in developing countries, commercial ELISA kits have high sensitivities but low specificities. A higher sensitivity and specificity were reported when using the antigen prepared from local $H$. pylori isolates than the commercial ELISA reagent kits ((38-40) for the diagnosis of $H$. pylori infection. In comparison between male and female, in this study the infection rate in males was higher than in females for both IgM and IgG detection and this will be in agreement with Deankanob et al, 2006, thirty-nine (60.9\%) of the males and $18(50.0 \%)$ of the females were seropositive, and disagreement with Andersen, etal, 1996(40). Which they reported that IgM seroprevalence indicate that women have a higher risk of primary $H$. pylori infection than do men in adult life. In this study we concluded that ELISA can be used for the detection of specific $\operatorname{IgM}$ and $\operatorname{IgG}$ to $H$. pylori and that the presence or absence of $\operatorname{IgM}$ and $\operatorname{IgG}$ antibodies to $H$. pylori may reflect whether or not an acute or chronic infection exists. We concluded that ELISA can be used for the detection of specific IgM to $\mathrm{H}$. pylori and that the presence or absence of IgM antibodies to $H$. pylori may reflect whether or not an acute infection exists.

\section{REFERENCES}

1) McGuigan, J. E., "Peptic ulcer and gastritis". $12^{\text {th }}$ Ed. McGraw-Hill, New York. (1978).

2) Wyatt J. I. and Dixon M. F., J Pathol.,154:113-124 (1988).

3) Graham D. Y., J Gastroenterol Hepatol., 6:105-113 (1991).

4) Parsonnet J., Friedman G. D., Vandersteen D. P., Cheng Y., Vogelman D. E. E., and Orentreich M. J. Med., 325:1127-1131(1991). 
5) Sugiyama T., Imai K., Yoshida H., Takayama Y., Yabana T., Yokota K., Oguma K. and Yachi A. Gastroenterology, 101:77-83(1991).

6) Warren J. R. and Marshall B., Lancet, i:1273-1275(1983).

7) Cutler A. F., Am J Med.,100:35-9S(1996).

8) Greenberg P. D., Koch J.and Cello J. P., Am. J. Gastroenterol., 91:228-232(1996).

9) Genta R. M. and Graham D. Y., J.Gastrointest. Endosc.,40:342345(1994).

10) Hazell S. L., Hennessey W. B., Borody T. J., Carrick J., Ralston M., Brady L. and Lee A. Am. J. Gastroenterol., 82:297-330(1987).

11) Taylor D. N., Blaser M. J., Epidemiol. Rev.,13:42-59(1991).

12) Marshall B. J., Am. J. Gastroenterol., 89: 116-128(1994).

13) Jensen A. K., Andersen L. P., Wachmann C. H., AP. MIS., 101:795801 (1993).

14) Sobala G. M., Crabtree J. E., Dixon M. F., Gut, 32:1415-18(1991).

15) Moms A., Nicholson G. Am. J. Gastroen-terol, 82:192-9(1987).

16) Talley N. J., Newell D. G., Ormand J. E., Carpenter H. A., Wilson W. R., Zinsmeister A. R, Perez-Perez G. I., and Blaser M. J., J. Clin. Microbiol, 29:1635-1639(1991).

17) Wulffen V. H., Grote H. J., Gatermann S., Loning T., and Berger B., J. Clin. Pathol., 41:653-659(1988).

18) Wyatt, J. I., and Rathbone B. J., J. Gastroenterol. Suppl. 142:44 49 (1988).

19) Crabtree, J. E., Mahony M. J., Taylor J. D., Heatley R. V., Littlewood J. M., and Tompkins D. S., J. Clin. Pathol., 44:768-771 (1991).

20) Dunn B. E., Campbell G., Perez-Perez G. I., and Blaser M. J., J. Biol. Chem., 265:9464-9469 (1990).

21) Hirschl, A. M., Pletschette M., Hirschl M. H., Berger J., Stanek G., and Rotter M. L., Eur. J. Clin. Microbiol. Infect. Dis. 7:570-575 (1988).

22) Stacey A. R., Hawtin P. R., and Hewell D. G., Eur. J. Clin. Microbiol. Infect. Dis. 9:732-737(1990).

23) Sobala, G. M., Crabtree J. E., Pentith J. A., Rathbone B. J., Shalicross T. M. Wyatt., Dixon J. I, Heatley R. V., and Axon A. T. R., Lancet 338:94-96(1991).

24) Solnick, J. V., and Tompkins L. S., Infect. Agent Dis. 1:294-309 (1993).

25) Chae, H. L. Kyung, D. Chung, S.K. Moon, K. J. and Seok, H., K.J.C.P, Vol.8, No. 1, 1988. 
26) Crabtree J. E., Mahony M. J., Taylor J. D., Heatley, Littlewood J. M., and Tompkins D. S., J. Clin. Pathol. 44:768-771(1991).

27) Perez-Perez, G. I., Dworkin B. M., Chodos J. E., and Blaser M., J. Ann. Intern. Med. 109:11-17 (1988).

28) Blaser M. J., J. Infect. Dis. 161:626-633(1990).

29) Wilson, M. R., Mulligan S. P., and Raison R. L., J. Immunol. Methods 107:231-237(1988).

30) Van de W.,, de Boer W. A, Jansz A. R., Staals A. P., Roymans R. T., Neth. J. Med., 47: 272-7(1995).

31) Ansorg, R. G., Recklinghausen G. V., Pomarius R., and Schmid E. N., J. Clin. Microbiol. 29:51-53(1991).

32) Goodwin C. S., Blincow E., Peterson G., Sanderson C., Cheng W., Marshall B., Warren J. R., and McCulloch R., J. Infect. Dis. 155:488494 (1987).

33) Loffeld R. J., and Stobberingh E., (poster 43). Fourth Workshop Gastroduodenal Pathology and Helicobacte rpylori. Ital. J. Gastroenterol., 23:24 (1991).

34) Megraud, F., S. Bouchard, Mayo K., and Camou C., (poster 45). Fourth Workshop Gastroduodenal Pathology and Helicobacter pylori. Ital. J. Gastroenterol., 23:25(1991).

35) Perez-Perez G. I., Taylor D. N., Bodhidatta L. Wongsrichanalai J., Baze W., Dunn B., Echeverria P. D. and Blaser M. J., J. Infect. Dis., 161:1237-41(1990).

36) Lin T. T., Yeh C.T., Yang E. and Chen P. C., J. Gastroenterol., 31: 329-32 (1996).

37) Hanvivatvong O., Tatiyakavee K., Thong-Ngam D., Wutichai W., Chariya C., Chariya H., and Pewpan M., J. Med. Assoc. Thai., 85: S383-388(2002).

38) Bodhidatta L., Hoge C. W., Churnratanakul S., et al., J. Infect. Dis.,168: 1549-53(1993).

39) Deankanob W., Chomvarin C., Hahnvajanawong C., Pewpan M. Wongwajana S., Mairiang P., Kularbkaew C., and Sangchan A., southeast asian J. trop med public health 37: 958-(2006).

40) Andersen L. P., Rosenstock S. J., Bonnevie O. and Jorgensen T., Am. J. Epidemiol., 143: 1157-1164(1996). 